\title{
Problem based learning: tutors' views 5 years after implementation at a sub-Saharan University
}

\author{
Moses Galukande ${ }^{1}$, Achilles Katamba ${ }^{2}$, Sarah Kiguli ${ }^{3}$,Elsie Kiguli-Malwadde ${ }^{4}$, \\ Stephen Kijjambu ${ }^{1}$, Nelson Sewankambo ${ }^{5}$
}

1. Surgery Department, College of Health Sciences, Makerere University

2. Clinical Epidemiology Unit, College of Health Sciences, Makerere University

3. Paediatrics Department, College of Health Sciences, Makerere University

4. Radiology Department, College of Health Sciences, Makerere University

5. Internal Medicine, College of Health Sciences, Makerere University

\begin{abstract}
Background: Curriculum evaluation is key to continuous assurance of quality of education.

Objectives: To assess the teachers' perceptions on how well student teaching and learning activities were conducted at an institution that had practiced PBL for five years.

Methods: A cross sectional descriptive study. 150 teachers from 23 departments at the College of Health Sciences participated in the study. A 25 item self-administered questionnaire was used to collect data. Activities evaluated included; students assessment, self-directed learning, feedback and clinical exposure. Data were entered in epi data and analysed using SPSS. Ethical approval was obtained.

Results: The participants' average teaching experience was eight years. The PBL/COBES approach mostly achieved the aim of producing self-directed and lifelong learners. Half of the teaching staff actively provided regular feedback about the learning and teaching activities they were involved in. Early clinical exposure was widely accepted as a highly rewarding appropriate teaching and learning strategy. COBES activities were well organized although involvement of College staff was low.

Conclusion: PBL/COBES program was successfully executed and had high acceptance among Faculty. The biggest challenge was getting all staff to provide regular feedback. Self institutional curriculum review can be done cheaply and quickly to provide feedback for continual curriculum improvement.
\end{abstract}

Key words: Problem Based Learning, Evaluation, Curriculum, University

DOI: http://dx.doi.org/10.4314/ahs.v15i1.34

\section{Introduction}

This curriculum evaluation exercise surveyed the teachers' opinions and perceptions of how a new curriculum implementation at the five year point was understood and implemented.

Five years of implementing new innovative methods of teaching and learning at Health sciences at Makerere University (an over 90 year old institution) was

\section{Correspondence author: \\ Moses Galukande \\ Department of Surgery \\ College of Health Sciences \\ Makerere University \\ P.O. Box 7072 \\ Mulago Hill Road \\ Kampala, Uganda \\ Email: mosesg@img.co.ug}

a milestone in the institution's educational history. A milestone because change for the better was embraced. The premise for the change was anchored in an extensive stakeholders' feedback exercise that had been con- ducted seven years earlier1. The extensive stakeholders' survey had been prompted by not only an awareness of global trends but also a need to respond to calls for change from alumni, employees and others stakeholders. These stakeholders in one way or another were involved with the graduates of this College. Stakeholders' demands can be achieved by continuous selfreflection and reforms.

Community Based Education and Service (COBES) is a system where students on an annual rotation basis are placed in a preselected rural site under the supervision of a preceptor for a period of 4-6 weeks with a predetermined set of educational and health service delivery targets. This process is supported by 
teachers at the College. Support is mostly in form Methods of traveling to supervise student and preceptors on Design:

site. These reforms are part of the edu cation evolution A cross sectional descriptive study. process at Makerere University

At Makerere University, curriculum reforms occurred All teaching staff from Makerere University College turning a predominately traditional teacher centred lec- of Health Sciences (without the School of Public ture based approach to a principally student centred, Health) and the National Referral hospital, Mulago self-directed and small group learning described as a and in 23 departments. The teachers involved in this combination of Problem Based Learning and Com- survey had a mean of eight years of teaching experimunity Based Education and Services (PBL/COBES) ence. The majority were specialists in the Clinical and methodologies. The COBES component involved Basic Sciences areas.

students spending part of the in-scheduled teaching

time at a pre-selected prepared rural community site Student learning:

where the (students) engaged in Health Service Deliv- The eight questions in this domain were about ery activities ${ }^{2}$. This exercise accorded them the oppor- PBL as an appropriate strategy for achieving skills in tunity to practice and learn in the context of a rural problem identification, and problem- solving through community life where nearly $90 \%$ of the country's pop- team work and appropriate use of resources. The other ulation lives ${ }^{3}$.

These curriculum reforms were not fully accepted by some stakeholders (including students, alumni, and the teachers). Some students and teachers preferred the lecture methods and some alumni thought reforms meant less teacher supervision.

The purpose of this survey therefore was to assess the strengths and weaknesses of the curriculum design and its implementation. This would inform strategies for improving the teaching and learning environment and the overall quality of education for undergraduate education at Makerere College of Health Sciences.

\section{Study area:}

Makerere University College is a 90 year old institution. It runs both undergraduate and graduate and 250 faculty (full, part- time to adjunct) ${ }^{4}$. The current educational reforms that started in 2003 have included over 250 sensitization/training workshop days and eight members completing courses in Masters of Health Profession Education. A complete transformation from teacher centred, lecture based to PBL/COBES curriculum was achieved after three years of preparation and implementation.

A quality assurance unit incorporated during the implementation period, formulated a manual stipulating minimum standards of education. This was informed by the World Federation of Medical Education standards (WFME) frame work ${ }^{5}$.

\section{Data tool:}

A pre-tested 25 item self-administered hard copy hand delivered questionnaire was used. It had both the 5

were Stu dent Learning (7), Student Assessment (6), COBES (5) and Governance (6 items).

The choice of the four domains was generated by consensus in a pre-planning meeting attended by the investigators and key representatives of the College educational committee drawing on WFME and other

literature $1,5,6,7,8,9,10$. These domains were organisational culture, learning contexts and organizational values Pretesting was done using 10 questionnaires given to to improve clarity of the items and questions

\section{Data collection:}

The questionnaires were sent to the 23 department after prior communication inviting members with a least 5 years teaching experience to participate voluntarily. Trained research assistants followed up the questionnaires. 150 questionnaires out of the 250 were returned and 107 were completely filled.

\section{Data analysis:}

Epi data program was used for the data entry. SPSS 12 version was used for analysis, standard descriptive statistics were performed for the different domains.
Ethical approval:

Results

Ethical approval was obtained from Makerere College Twenty one departments were represented as shown in of Health Sciences, School of Medicine Research and table I, though 16 respondents did not indicate the deEthics Committee. partments they represented.

Table 1: Departmental representation of the returned questionnaires from respondents at College of Health Sciences,

Makerere 2010

\begin{tabular}{lc}
\hline Department & $\begin{array}{c}\text { Surveyed Tutors } \\
\text { Number (\%) }\end{array}$ \\
\hline Medical & $30(28)$ \\
Surgical & $29(27)$ \\
Pre-Clinical & $24(22)$ \\
Radiology & $6(6)$ \\
Nursing & $7(7)$ \\
Dentistry & $4(4)$ \\
Pharmacy & $7(7)$ \\
Total & $\mathbf{1 0 7 ( 1 0 0 )}$ \\
\hline
\end{tabular}
point Likert and binary scales. Items in four domains 10 individuals. The appropriate adjustments were made College of Health Sciences, Makerere 2010

Student learning

\begin{tabular}{|c|c|c|c|c|c|}
\hline & & \multicolumn{4}{|c|}{ Number (\%) } \\
\hline & & Agree & Disagree & Neutral & Total \\
\hline 1. & $\begin{array}{l}\text { The PBL curriculum has empowered students to identify } \\
\text { health problems and use available resources and } \\
\text { information to address them. }\end{array}$ & $75(70)$ & $11(10)$ & $21(20)$ & 107 \\
\hline 2. & $\begin{array}{l}\text { Problem Based Learning has helped our students to } \\
\text { appreciate the complexity of diseases and health } \\
\text { problems, diagnostic technologies as well as treatment } \\
\text { regimens which require continued learning. }\end{array}$ & $67(63)$ & $10(9)$ & $30(28)$ & 107 \\
\hline 3. & $\begin{array}{l}\text { Our new PBL approach to student learning has } \\
\text { reinforced "team work" study in small groups focused on } \\
\text { problems with teachers facilitating the learning process. }\end{array}$ & $93(87)$ & $5(5)$ & $9(8)$ & 107 \\
\hline 4. & $\begin{array}{l}\text { Communication skills are more likely to be developed } \\
\text { under the PBL curriculum through varied learning } \\
\text { opportunities. }\end{array}$ & $89(83)$ & $7(7)$ & $11(10)$ & 107 \\
\hline 6. & I am involved in the planning teaching activities. & $50(47)$ & $19(18)$ & $38(36)$ & 107 \\
\hline 7. & $\begin{array}{l}\text { When I encounter challenges in facilitating the learning } \\
\text { process (teaching), I am listened to and helped. }\end{array}$ & $64(60)$ & $17(16)$ & $26(24)$ & 107 \\
\hline 8. & I regularly provide administrative feedback. & $64(60)$ & $15(14)$ & $28(26)$ & 107 \\
\hline
\end{tabular}

African Health Sciences Vol 15 Issue 1, March 2015 
COBES performance was rated highly in all the five was implemented effectively. It contributes to continquestions, $64-94 \%$ were in agreement of high scores uous professional development for the site preceptors. (see table 3) that COBES gave the desirable rural com- The challenges faced during COBES were often well munity health exposure experience to students and, it articulated.

\section{Table 3: COBES performance rating by staff, College of Health Sciences, Makerere 2010}

\section{Community Based Education and Services (COBES)}

\begin{tabular}{|c|c|c|c|c|c|}
\hline \multicolumn{6}{|c|}{ Community Based Education and Services (COBES) } \\
\hline \multirow[b]{2}{*}{1.} & & Yes & No & & \\
\hline & Are you involved in COBES? & 47 (44) & $60(56)$ & & 107 \\
\hline & & \multicolumn{4}{|c|}{ Number of those involved (\%) } \\
\hline & & Agree & Disagree & Neutral & Total \\
\hline 2. & $\begin{array}{l}\text { COBES has given students an exposure to rural } \\
\text { health care. }\end{array}$ & $44(94)$ & $3(6.4)$ & & 47 \\
\hline 3. & COBES program is implemented effectively. & $33(70)$ & $8(17)$ & $6(13)$ & 47 \\
\hline 4. & $\begin{array}{l}\text { COBES contributes to Continuous Professional } \\
\text { Development for site tutors. }\end{array}$ & $41(87)$ & $2(4)$ & $4(9)$ & 47 \\
\hline 5. & COBES challenges are well articulated & $30(64)$ & $9(19)$ & $8(17)$ & 47 \\
\hline
\end{tabular}

The four questions about COBES included the justification for it, running the COBES program and feedback about how it was run.

The teachers evaluated the assessment methods, inte- ulated learning for $73 \%$ of students. Integration was gration of teaching and early clinical exposure (see table perceived to be attained by $76 \%$ of the participants. 4). The majority $61 \%$ agreed that assessment methods Examination guidelines were not clear to at least $16 \%$ employed under PBL were aligned with the teaching of the respondents.

methods. Early student contact with real patient stim-

Table 4: Student assessment ratings by; assessment methods, integration and early clinical exposure (the assessment was by staff), College of Health Sciences, Makerere 2010

\begin{tabular}{|c|c|c|c|c|c|}
\hline \multicolumn{6}{|c|}{ Assessment } \\
\hline \multirow[b]{3}{*}{1.} & & & Number & (\%) & \\
\hline & & Agree & Disagree & Neutral & Total \\
\hline & $\begin{array}{l}\text { Assessment methods employed under the } \\
\text { PBL curriculum are in alignment with } \\
\text { teaching methods. (What is assessed is } \\
\text { what is learned }\end{array}$ & $65(61)$ & $15(14)$ & $27(25)$ & 107 \\
\hline 2. & $\begin{array}{l}\text { Early student contact with real patients } \\
\text { stimulates their learning }\end{array}$ & 78 (73) & $11(10)$ & $18(17)$ & 107 \\
\hline 3. & $\begin{array}{l}\text { Horizontal integration of biomedical } \\
\text { sciences is important for student learning. }\end{array}$ & $76(71)$ & $6(6)$ & $25(23)$ & 107 \\
\hline 4. & $\begin{array}{l}\text { Verticical integration of clinical and } \\
\text { biomedical sciences facilitates better } \\
\text { learning. }\end{array}$ & $81(76)$ & $5(4.7)$ & $21(20)$ & 107 \\
\hline & $\begin{array}{l}\text { The guidelines regarding students } \\
\text { attendance at examinations are clearly } \\
\text { stated. }\end{array}$ & $69(65)$ & $17(16)$ & $21(20)$ & 107 \\
\hline 6. & $\begin{array}{l}\text { Students receever regular and timely } \\
\text { assessment feedback under the PBL } \\
\text { curriculum. }\end{array}$ & $56(52)$ & $19(18)$ & $32(30)$ & 107 \\
\hline
\end{tabular}

Only half of the staff that participated in this survey More than a third (38\%) viewed the use of available viewed the introduction of the PBL/COBES curricu- resources as optimally managed, however $75 \%$ viewed lum as positively transformative of the College teaching the College of Health Sciences as having the potential and learning landscape (see table 5). for greater administration, financial and management efficiency.

\section{Table 5: Key Governance aspects ratings as assessed by staff}

\begin{tabular}{|c|c|c|c|c|}
\hline \multicolumn{5}{|l|}{ Governance } \\
\hline & \multicolumn{4}{|c|}{ Number (\%) } \\
\hline & Agree & Disagree & Neutral & Total \\
\hline $\begin{array}{l}\text { 1. The transformation of the to a College of Health Sciences } \\
\text { potentially provides for meaningful synergy between the } \\
\text { various streams of medicine, public health, nursing, } \\
\text { pharmacy and dentistry to better meet the educational } \\
\text { challenges of the } 21 \text { st century }\end{array}$ & $\begin{array}{l}115 \\
(86)\end{array}$ & $7(5)$ & $12(9)$ & 100 \\
\hline $\begin{array}{l}\text { 2. The introduction of the } \mathrm{PBL} / \mathrm{COBES} \text { curriculum facilitated } \\
\text { the transformation of the College and this new curriculum } \\
\text { had a positive effect at the University. }\end{array}$ & $73(51)$ & $20(14)$ & $50(35)$ & 100 \\
\hline $\begin{array}{l}\text { 3. The establishment of a CHS is better placed to meet the } \\
\text { shortage of health care providers at all levels of the system } \\
\text { than the Faculty of Medicine, through the establishment of } \\
\text { four Schools (Public Health, Medicine, Health Sciences and } \\
\text { Bio-medical Sciences). }\end{array}$ & $\begin{array}{l}103 \\
(73)\end{array}$ & $16(11)$ & $22(16)$ & 100 \\
\hline $\begin{array}{l}\text { 4. The resources available have been optimally utilized and } \\
\text { managed. }\end{array}$ & $55(38)$ & $30(21)$ & $59(41)$ & 100 \\
\hline $\begin{array}{l}\text { 5. The CHS has the potential for greater administrative, } \\
\text { financial and management efficiency }\end{array}$ & $\begin{array}{l}106 \\
(75)\end{array}$ & $9(6)$ & $27(19)$ & 100 \\
\hline 6. I understand the PBL/COBES management structures. & $79(56)$ & $26(19)$ & $35(25)$ & 100 \\
\hline
\end{tabular}

\section{Discussion} prograt was $\mathrm{PBL} / \mathrm{COBES}$ ceptance by the teachers (tutors).

\section{PBL succes}

Concerning student learning, seventy to eighty percent of the teachers judged that PBL had achieved the general intended aims of students attaining problem solving skills and working as a team. The teachers responded to a set of questions in order to judge whether PBL had achieved its intended purpose. These teachers had been involved since the inception of PBL and COBES, and had previously undergone over 250 workshop days of training in various aspects of teaching and learning. These included but not limited to exploiting knowledge of how people learn to promote effective learning and dealing with the challenges of running successful turespondents were all well grounded in the basic knowledge of the principles that underpin the practice of PBL/COBES and therefore qualify to pass judgment on its execution.

Problem solving is a basic tenet of the philosophy of teaching and learning in this regard. Faculty should be engaged in identifying better ways of implementing the problem solving aspect in a PBL curriculum. It is therefore important that there exists a mechanism that ensures Faculty frequently and regularly give feedback to the curriculum implementation committee or its equivalent. For five years, feedback was gathered through regular weekly two hour long meetings at the College of Health Sciences. 
Overall, fifty percent of the teachers in this study regularly provided feedback. Feedback concerning implementation challenges including both academic and administrative. This proportion was slightly different from those that were involved in planning learning activities; it is therefore possible though not necessarily so that those involved in planning are also involved in giving regular feedback.

Whereas fifty percent of the staff provided feedback and this is to be judged as good involvement, it is debateable as to what the benchmark involvement in giving feedback should be. Involvement would be defined as in numbers of teachers giving feedback the scope an detail of feedback.

Regular and timely feedback to students after assessment is crucial for learning and was an area for definite improvement in this evaluation. It may involve training staff on how to provide feedback and for students what feedback to expect. Students' polls to assess what percentage of them feel they get feedback and their level of satisfaction could be part of improving feedback management $t^{14}$.

Feedback should be immediate, inexpensive, it should require little preparation (but requires skill in giving it and should be highly desirable to the learner. Frequency coupled with a user friendly mechanism ${ }^{15}$ ensures steady flow of feedback, but it is also important that the administrative team responds to the feedback given ${ }^{16}$ in an appropriate and timely manner.

Alignment of teaching methods and assessment refers to using assessment methods appropriate to the style of teaching. It is also assessing students in a way simlar to how teaching and learning occurred. Alignment was judged as well done by nearly two thirds of the respondents. Assessment drives learning, students learn in the way they are would be assessed ${ }^{17}$. Alignment of these two is critical and they feed into each other in order to achieve learning. Student assessment should therefore consider not only learning the objectives and content of the subject in question but also the method of learning, for example if group work is employed in a significant way, group assignments should be a significant part of the assessment portfolio. xaminations are a central part of curriculum impleExentation and therefore examiners and students should be absolutely clear about examination regulations. Exams are part of assessment, a lens through which an institution assesses itself through its students work. When assessment results do not match institutional or programmatic expectations, that is the time for the staff to collectively determine how to improve student performance. So it is critical that the rules by which these assessments run are clear and well understood ${ }^{18}$. In the evaluation a third of the teachers were not clear about exam regulations. All staff should be in the know of all the regulations and rules.

An assessment blue print including examination regulations and in house trainings program may be the way forward in resolving this situation.

\section{Community Based Education and Service}

\section{(COBES)}

Early clinical exposure as an essential strategy to teaching and learning was agreed on by the majority of the respondents. There was a significant buy-in of the concept. Early clinical exposure aids integration of basic and clinical studies. This integration aids better retention of knowledge and acquisition of skills. Better retention translates knowledge and acquisition of skills for competence development.

The teachers involved in COBES activities were 39\% of the teaching staff. Where, there is no set target of how many teachers should be actively involved. It is desirable that as many as can do participate, perhaps a rotation policy would get more staff involved but it would sacrifice the advantage of experience and continuity for this smaller group (44\%) that has already demonstrated exceptional interest and expertise. However COBES activity supervision is also taken on by site tutor or pre-receptors and staff from the school of Public Health who were not included in the $44 \%$

COBES was effectively implemented as judged by $70 \%$ of the respondents. One of the purposes of COBES was to expose students to rural health, whether this exposure translates into students going back to work in these areas after training awaits to be seen ${ }^{19,20}$.

In a previous study by Mubuuke et $\mathrm{a}^{20,21}$; that interviewed radiology COBES students at Makerere revealed that the students understood the importance and purposes of participating in learning activities in the community. ssues of governance were explored through question of education reform, resource utilization, professional development and program evaluation. The majority of teachers understood the justification of the transformation to the College status however, resource usage in general was judged as poor $20 \%$ and $(50 \%$ were The word resource implied time, equipment, staff, infrastructure as well as money, though we urge that whenever a question regarding resources availability and usage is raised, a negative response is expected given the realities of general in most Higher Education institutions in resource poor environment.

The creation of a College of Health Sciences (a higher functional status that carries with it semi autonomy) was a governance matter, that was conceived as reframing and questioning the previous vision and its interpretation. In addition it focused on both the internal and external governance models with the aim of drawing strategic direction.

It was anticipated that the College will realize mor funding, more collaborations, a higher research output, more student enrolment and more staff recruitment and retention. More than it would have had it not transformed. Continuous professional development by way of regular refresher courses in select priority areas should be on going to help old and new faculty understand in depth how the new innovative methods of learning and teaching work as well as how they would make it work.

Periodic self-institutional evaluations to track improvements and areas of noncompliance ${ }^{22,23}$, as indeed this evaluation exercise was done, and should continue and be regularized.

Among the strengths of this study; there were no significant differences in responses between those who agreed, disagreed and or had neutral responses. This implies general consensus in the opinions shared.

Eligibility to participate was based in part on longevity of service. A five year teaching experience was deemed the minimum appropriate for one to be able to pas udgement on the various aspects outlined in the study.

\section{Study limitations}

This study was not without limitations, the unknown and therefore uncharacterized non-responders who could be the critiques of the changes implemented. The responses were self -reported and therefore may be subjective. However, over the implementation period and before numerous capacity building activities occurred. We believe this provided firm grounding in the understanding of PBL/COBES. This study mean to collect teachers' views only, so the students' views were missed.

\section{Conclusion}

Regular curriculum self evaluation is possible and may be adopted as part of a continuous curriculum improvement. PBL/COBES was over all well executed in resource limited environment.

\section{Competing Interest}

The authors declare no competing interests.

\section{Sources of funding for the work}

The College of Health Sciences, Makerere University.

\section{Author contributio}

SN, GM originated concept. GM, KA participated in data collection and analysis. GM wrote the first draft of the manuscript. All authors participated in the critical review for intellectual content. All authors approved the final manuscript

\section{References}

1. Galukande M, Kiijambu SC, Kiguli-Malwadde E Kiguli S, Mwanika A, Luboga S. Student and Tutor Perception of a New Problem Based Learning Curriculum at Faculty of Medicine, Makerere University. East and Central African Journal of Surgery. March / April 2008; 13(1): 7-14

2. Kiguli-Malwadde E, Kijjambu S, Kiguli S, Galukande M, Mwanika A. Problem based learning, curric ulum development and change process at Faculty of Medicine, Makerere University, Uganda. African Health Sciences. June 2006; 6(2): 127 - 130

3. Anonymous (2010). The Republic of Uganda Ministry of Finance, Planning and Economic development (2010) Millennium, Development Goals report for 
Uganda.

4. Makerere University College of Health Sciences: Strategic Plan 2009/10-2013/14. Kampala Makerere University ; 2009: 5-6

5. World Federation for Medical Education www. wfme.org/standards

6. Galukande M, Henk Van Berkel J, Wolfhagen I. A tool for measuring Quality of Medical Education. Edu cation for Health Journal. 2009 Aug; 22 (2)

7. Marangelo Ginty. A review of Evaluation studies of PBL across disciplines and the implications for our future practice: presentation to the HE Academy Health Sciences and Practice PBL special Interest Group 16/11/06, Kings College London.

8. Bigg J. Teaching for quality learning at University, Buckingham: 2003 Open University Press

9. Dolmans DH, GIjselaers WH, Moust JH, de Grave WS, Wolfhagen IH, van der Vleuten CP. Trends in research on the tutor in problem based learning: Conclusions and Implications for educational practice and research. Medical teacher 2002; 24(2): 173-180

10. Gibbs $G$ and Simpson C. Conditions under which assessment supports student learning. Learning and Teaching in Higher education 2004: 1(1): 3-31

11. Czabanowska K, Moust JHC, Meijer AWM, Schroder-Back P, Robertsen H. Problem Based Learning revisited, introduction of active and self directed learning to reduce fatigue among students. Journal of University Teaching and Leaning practice 2001; 9(1)

12. Wood EJ. Problem based learning: Exploiting knowledge of how people learn to promote effective learning.www.bioscience.hecademy.ac.uk/journal/ vol3/beej-3-5.aspx

13. Barrett T. The problem based learning process as finding and being in flow. Innovations in Education and Teaching International 2010:47(2):165-174

14. Dahlstrom J, Dorai-Raja, McGill D, Owen C, Tymms $\mathrm{K}$ and Watson AR. What motivates senior clinicians to teach medical students? BMC Medical Education 2005, 5:27 doi:10.1186/1472-6920/5/27.

15. Hewson MG, Little ML. Giving feedback in Medical Education verification of recommended Techniques. $J$ Gen Intern Med 1998; 13: 111-116.

16. Wood BP. Feedback: A key feature of Medical Training. Radiology 2000; 215:17-19.

17. Van der Vleuten CPM, Schuwirth LW'T. Assessing professional competence: From methods to programs. Medical Education 2005; 39: 309-317.

18. Maki PL. Developing an assessment plan to learn about student learning. The Journal of Academic Librarianship 2002; 28(1): 8-13

19. McAllisterA. Mc Ewery E, Frost N. Rural attachments for students in the Health Professions. Health Journals 2001;9: 14-18

20. Longome AO. Medical Schools in Rural areas-necessity or aberration? Rural and Remote Health 2009; 9:1131 21. Mubuuke AM, Kiguli-Malwadde E, Byanyima R, Businge F. Evaluation of Community Based Education and Service for Undergraduate radiology students at Makerere University, Uganda. Rural and Remote Health 2008; 976.

22. Biggs J. The reflective institution: Assessing and enbancing the quality of teaching and learning. Higher Education 2000; 41:221-238.

23. Yorke M. Developing a quality culture in higher education. Tertiary Education and Management 2000; 6:19-36. 